\title{
OPERATIONAL CHARACTERISTICS TUBE BENDS OF X10CrWMOVNb9-2 STEEL MADE IN THE BENDING PROCESS WITH LOCAL INDUCTION HEATING
}

\author{
${ }^{1}$ Marek CIEŚLA, ${ }^{1}$ Grzegorz JUNAK, ${ }^{2}$ Janusz TOMCZAK, ${ }^{3}$ Tomasz KAWAŁA \\ ${ }^{1}$ Silesian University of Technology, Faculty of Materials Science and Metallurgy, Katowice, Poland, EU, \\ marek.ciesla@polsl.pl \\ ${ }^{2}$ Lublin University of Technology, Faculty of Mechanical Engineering, Lublin, Poland, EU \\ ${ }^{3}$ ZRE Katowice S.A. Production Centre, Jaworzno, Poland, EU
}

https://doi.org/10.37904/metal.2019.816

\begin{abstract}
The paper contains results of theoretical and experimental research on the bending process of tube with dimensions of $530 \mathrm{~mm} \times 90 \mathrm{~mm}$, used in production of power pipelines of X10CrWMoVNb9-2 steel grade. The innovative process of pipe bending with the use of local induction heating and results of its numerical simulation (FEM) were presented. Modelling of tube bending was done using Simufact Forming 12.0 software. A change of the geometry in the cross-section of the bend area was subjected to analysis, including the ovalization of the cross-section and the wall thickness in the region subject to tensile and compression. The geometrical features of the bend determined on the basis of numerical calculations were compared with the measurement results obtained in industrial conditions. Basic mechanical properties of the tube in the as-delivered condition and of the fabricated tube bend were determined using tensile, hardness, impact, low-cycle fatigue and creep tests. It was proved that the tube bends made of the X10CrWMoVNb9-2 steel, subject to bending using the proposed technology, meets the requirements of the applicable standards.
\end{abstract}

Keywords: Tube bending, numerical modelling, mechanical properties, creep, low-cycle fatigue

\section{INTRODUCTION}

The construction of modern 1000MW supercritical coal-fired boilers is the main direction for power industry development in the current decade. The most modern materials, such as X10CrMoVNb9-1 or X10CrWMoVNb9-2 steels, must be taken into consideration in the design process for this kind of devices. These materials must be able to meet very high requirements in terms of the efficiency and availability expected by the user [1-6]. This applies specially to steam pipelines, which operate at a temperature equal or higher than $600{ }^{\circ} \mathrm{C}$ and under pressure exceeding $28 \mathrm{MPa}$. These objects are exposed mainly to the harmful effects of progressive changes in the material caused by, among others, creep processes and, in many cases, processes of thermo-mechanical fatigue of a low-cycle nature $[3,7,8]$.

Tube bends [9-11] are used in practically all power pipelines. Therefore, unconventional bending methods, including those using local heating of tubes during forming [12], are finding application in their production technology more and more often. A diagram of the tube bending with a local induction heating is shown in Figure 1.

The authors find it appropriate to undertake research oriented towards the determination of relations between the technological parameters of the tube bending process and the mechanical properties of the tube bend material, which should not diverge from the properties of the tube in its initial state (as delivered). Examination of the basic mechanical properties, as well as low-cycle fatigue and creep tests at a temperature of $600{ }^{\circ} \mathrm{C}$ have been carried out.

The test material consisted of a high-temperature creep resisting steel X10CrWMoVNb9-2 tube with dimensions $530 \mathrm{~mm} \times 90 \mathrm{~mm}$, which was thermally treated through normalization and tempering (heat treatment of NT type) and a tube bend made of this steel, formed at $950{ }^{\circ} \mathrm{C}$, with bending radius $1325 \mathrm{~mm}$, 
which was thermally treated through quenching and tempering (heat treatment of QT type). Industrial trials of forming tube bends were performed at Zakłady Remontowe Energetyki Katowice S.A.
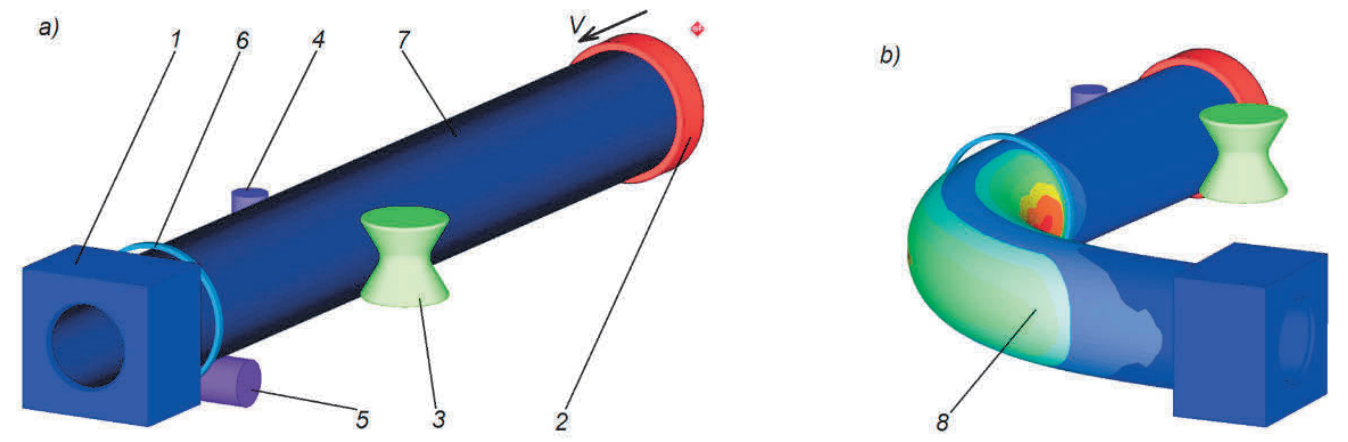

Figure 1 Diagram of tube bending: (a) before bending process, (b) after bending process, 1 - forming arm, 3, 4, 5 - guide rollers, 2 - clamping piece (tube pusher), 6 - inductor, 7, 8 - tube being bent, $\mathrm{V}$ - tube feed direction

\section{NUMERICAL MODELLING OF THE TUBE BENDING PROCESS}

Forming of a tube bend made of the X10CrWMoVNb9-2 steel, with the dimensions $530 \mathrm{~mm} \times 90 \mathrm{~mm}$ and bending radius $1325 \mathrm{~mm}$, was modelled. Calculations by means of the finite-element method (FEM) were conducted using the Simufact Forming software, version 12.0. This software was repeatedly used for numerical modelling of complex metal forming processes and the obtained results were successfully verified experimentally [13].

Numerical simulations of the tube bending process were carried out in the range of heating temperature of $850{ }^{\circ} \mathrm{C}-1050{ }^{\circ} \mathrm{C}$ at a feed rate of the pusher: $2.0-6.5 \mathrm{~mm} / \mathrm{min}$. The model of the material was developed based on plastometric compression tests and the examples of the flow curves are shown in Figure 2. It was assumed in the numerical simulation that a semi-finished product was heated right through along a $60 \mathrm{~mm}$ long segment, up to the forming temperature. The assumed initial temperature of the semi-finished product, the environment and tools, was $20^{\circ} \mathrm{C}$. The other parameters adopted for the calculations were as follows: the factor of friction between the semi-finished product and tools $m=0.3$ (constant friction model), material/tool heat exchange coefficient - $10 \mathrm{~kW} /\left(\mathrm{m}^{2} \cdot \mathrm{K}\right)$, heating ring/semi-finished product heat exchange coefficient - 100 $\mathrm{kW} /\left(\mathrm{m}^{2} \cdot \mathrm{K}\right)$, material/environment heat exchange coefficient $-0.35 \mathrm{~kW} /\left(\mathrm{m}^{2} \cdot \mathrm{K}\right)$ for cooling in standing air.

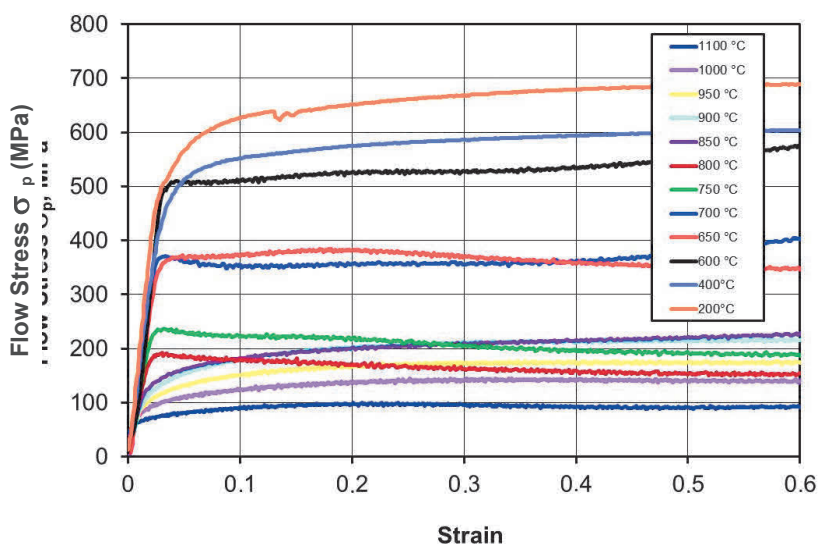

Figure 2 Flow curves of $\mathrm{X} 10 \mathrm{CrWMoVNb9-2}$ steel at deformation rate $0.1 \mathrm{~s}^{-1}$

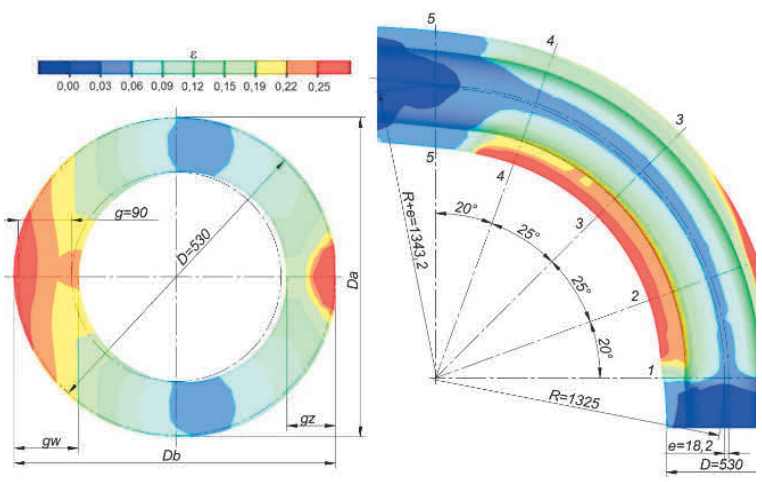

Figure 3 Change in the tube bend's section geometry (heating temperature: $950{ }^{\circ} \mathrm{C}$ ) 
The optimal geometry of the bend in its cross- and longitudinal section, determined using FEM, is shown in Figure 3. Measurements of geometrical parameters were taken in five cross-sections (marked in Figure 3), perpendicular to the bend's axis. The shape of the tube bend is characterised by slight ovalization of the section (ca. $0.55 \%$, Table 1). An increase in the wall thickness was observed within the internal area of the bend, where compressive stresses predominate, and thinning of the walls within the external area, where tensile stresses prevail.

Table 1 Geometrical parameters of the tubes subject to bending, obtained in FEM simulation (temp. $900{ }^{\circ} \mathrm{C}$ )

Geometrical features of the bend

bending radius $R=1325 \mathrm{~mm}$, shift of the neutral axis $e=18.2 \mathrm{~mm}$

\begin{tabular}{|c|c|c|c|c|c|c|}
\hline Bend section no. & $1-1$ & $2-2$ & $3-3$ & $4-4$ & $5-5$ & Mean value \\
\hline Wall thickness in the tensioned zone of the bend $g_{z}(\mathrm{~mm})$ & 81.2 & 80.4 & 81.6 & 82.6 & 86.1 & 82.4 \\
\hline Wall thickness in the compressed zone of the bend $g_{w}(\mathrm{~mm})$ & 109.5 & 108.9 & 108.4 & 107.4 & 108.3 & 108.5 \\
\hline Large axis of the ellipsis $D_{b}(\mathrm{~mm})$ & 535.5 & 529.2 & 530.9 & 531.6 & 534.2 & 532.3 \\
\hline Small axis of the ellipsis $D_{a}(\mathrm{~mm})$ & 533.5 & 532.1 & 533.2 & 532.5 & 531.4 & 532.5 \\
\hline $\begin{array}{c}\text { Section ovalization } e(\%) \\
e=\frac{D_{a}-D_{b}}{D} \cdot 100 \%\end{array}$ & 0.38 & 0.55 & 0.43 & 0.17 & 0.53 & 0.41 \\
\hline
\end{tabular}

During the FEM analysis the Cockroft-Latham fracture criterion was also taken into account. The analysis of the Cockroft-Latham failure criterion (Figure 4) shows that its highest values occur in the external radius zone of the tube bend. This is the area with the highest tensile stress which may lead to material cracking. The obtained Cockroft-Latham integral values are relatively low (ca. 0.2). For typical constructional steels, threshold of the Cockroft-Latham criterion adopts values within the range $0.7 \div 1$.

The obtained results of numerical simulation of bending tubes made of X10CrWMoVNb9-2 steel show that the resultant deformation (cross-section ovalization) is much lower than the admissible values. An increase of the heating temperature (within the range of $850{ }^{\circ} \mathrm{C}-1050{ }^{\circ} \mathrm{C}$ ) affects the geometry of the formed bends to a small degree. The significant inhomogeneity of the obtained stress and strain distributions in the area of

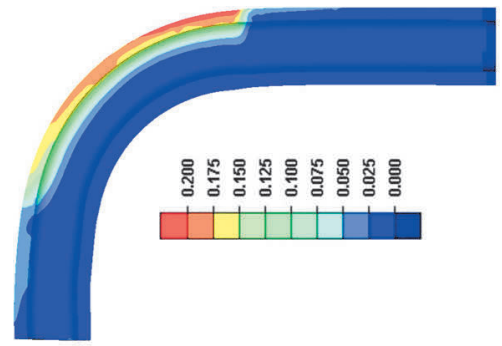

Figure 4 FEM-determined distributions of CockroftLatham failure criterion at the final stage of tube bending the bend formed affects the strength parameters of the tubes subject to bending. Therefore, the so-formed semi-finished products are subjected to heat treatment, the main purpose of which is to homogenize the mechanical properties within the bending zone and in the non-deformed segments of the tube.

Optimal tube bending parameters, in terms of the geometrical features of the bend and force parameters of the bending process, as well as economic indicators, were defined, based on numerical simulations. The defined optimal tube bending parameters were applied in the process carried out in industrial conditions.

\section{INDUSTRIAL TRIAL OF INDUCTION TUBE BENDING}

Forming of tube bends for power engineering applications was performed at Zakłady Remontowe Energetyki Katowice S.A. The parameters of bending and QT treatment (quenching and tempering) were selected based on numerical calculations, ZRE Katowice's own experiments and the PN-EN10216-2 standard. An induction bending machine was used, which enables tube bending in the range of diameters $D=168.3 \div 1220 \mathrm{~mm}$ with 
wall thickness of $g=5 \div 100 \mathrm{~mm}$ in the area of bending angles $\alpha=0 \div 180^{\circ}$. A characteristic feature of the bend formed was a great compliance of its geometry with the outline determined in FEM numerical analysis. When analysing the geometry of the formed bend, a considerable change in the wall thickness can be observed (similar to that determined numerically), while the change in the wall thickness of the formed bend falls within the range acceptable by appropriate standards.

The minimum wall thickness in the tensioned zone amounted to $g=80.5 \mathrm{~mm}$ and was greater than the minimum thickness defined by the standard $(g=60 \mathrm{~mm})$. At the same time, the measured minimum wall thickness of the bend in the compressed zone amounted to $\mathrm{g}=104 \mathrm{~mm}$ and was greater than the minimum defined by the standard $(g=72 \mathrm{~mm}$ ). Also, a slight deformation (ovalization) of the formed bend's cross-section occurred, whose maximum measured value was $e=0.6 \%$, which was much lower than the admissible $e=8 \%$.

\section{TEST RESULTS AND THEIR ANALYSIS}

Evaluation of principal mechanical properties of a $530 \mathrm{~mm} \times 90 \mathrm{~mm}$ tube in its as-delivered condition after heat treatment of NT type (normalizing and tempering) and of the bend formed from this tube after heat treatment of QT type (quenching and tempering), was performed based on the results of a tension, hardness and impact tests. Testing material was sampled from 3 zones of the tube bend and from tube.

The test results concerning the principal mechanical properties of the investigated materials are collated in Table 2. On the basis of their analysis it can be ascertained that the material of the bend formed from the X10CrWMoVNb9-2 steel meets the requirements set forth in the PN-EN 10216-2 standard.

For selected zones of the bends and the as-delivered tube material, low-cycle fatigue tests were carried out. The tests simulated plastic deformation in the unsteady operation conditions of a power unit that is possible to occur in pipelines subject to the highest effort. The fatigue tests were conducted using a servo-hydraulic strength testing machine MTS on cylindrical specimens with a diameter of $12 \mathrm{~mm}$. The tests were conducted at an elevated temperature of $600{ }^{\circ} \mathrm{C}$ with the machine being controlled by deformation at a constant frequency of the strain change of $0.1 \mathrm{~Hz}$. The tests were performed for the total strain range of $\Delta \varepsilon_{t}=0.6 \%$.

Table 2 Mechanical properties of the X10CrWMoVNb9-2 steel tube and of the bend at room temperature

\begin{tabular}{|c|c|c|c|c|c|c|c|}
\hline Sampling place & Sample design. & $\begin{array}{c}\mathrm{R}_{\mathrm{m}} \\
(\mathrm{MPa})\end{array}$ & $\begin{array}{c}\mathrm{R}_{\mathrm{p} 0,2} \\
(\mathrm{MPa})\end{array}$ & $\begin{array}{c}\mathrm{A} \\
(\%)\end{array}$ & $\begin{array}{c}\mathrm{Z} \\
(\%)\end{array}$ & $\begin{array}{c}\mathrm{KV} \\
(\mathrm{J})\end{array}$ & $\begin{array}{c}\mathrm{HV} 10 \\
\left(\mathrm{kG} / \mathrm{mm}^{2}\right)\end{array}$ \\
\hline tube: as-delivered & 1 & 722 & 578 & 25.5 & 68.5 & 128 & 230 \\
\hline bend: straight segment behind the bend & 2 & 685 & 547 & 24.8 & 67.5 & 123 & 218 \\
\hline bend: tensioned zone & 3 & 697 & 548 & 24.9 & 66.9 & 109 & 222 \\
\hline $\begin{array}{c}\text { bend: compressed zone } \\
\text { Properties in accordance with }\end{array}$ & 4 & 741 & 603 & 20.5 & 66.0 & 111 & 235 \\
\hline \multicolumn{2}{|c|}{$P N-E N$ 10216-2 } & $620 \div 850$ & min 440 & min. 19 & - & min. 27 & $200 \div 260$ \\
\hline
\end{tabular}

Based on the results, the number of cycles until specimen's fracture $\left(N_{f}\right)$ was determined. The developed characteristics of fatigue durability are shown in Figure 5. The recorded fatigue durability values, $N_{f}$, for the tube bend material were higher than for the tube material in the as-delivered condition, which indicates greater ability of the bend to transfer loads of a low-cycle nature. This testifies to the decrease of strength properties of the material in the conditions of cyclic loadings of an elastic-plastic nature.

Creep tests were conducted to characterize the behaviour of the tube material in the steady operating conditions of a power installation. Creep tests of the materials characterised in Table 2 were performed on an ATS-2330 machine in the Institute of Aviation, Warsaw. The tests were carried out at a temperature of $600{ }^{\circ} \mathrm{C}$ 
under stress of $162 \mathrm{MPa}$. The developed characteristics of creep are shown in Figure 6. Analyses of them show, in zones of tensile and compression of the bend, its deformation $(\varepsilon)$ is lower during creep tests, this means behaviour of the material bend is much better in comparison with the as-delivered tube.

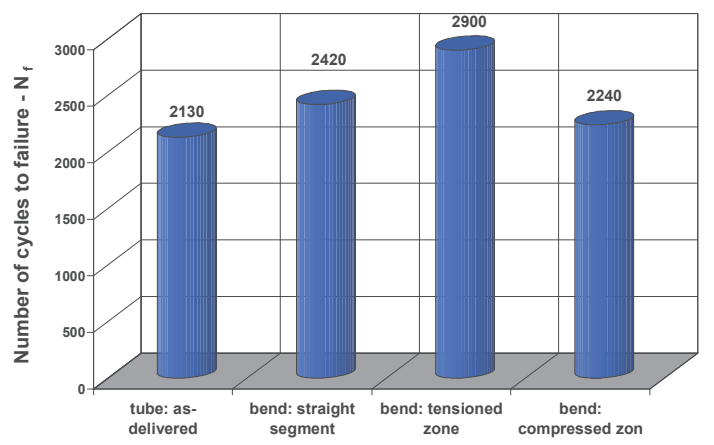

Figure 5 Diagrams of low-cycle durability $\left(N_{f}\right)$ of the $\mathrm{X} 10 \mathrm{CrWMoVNb9-2}$ steel tube material and of the tube bend at a temperature of $600{ }^{\circ} \mathrm{C}$ for the total strain range $\Delta \varepsilon_{t}=0.6 \%$

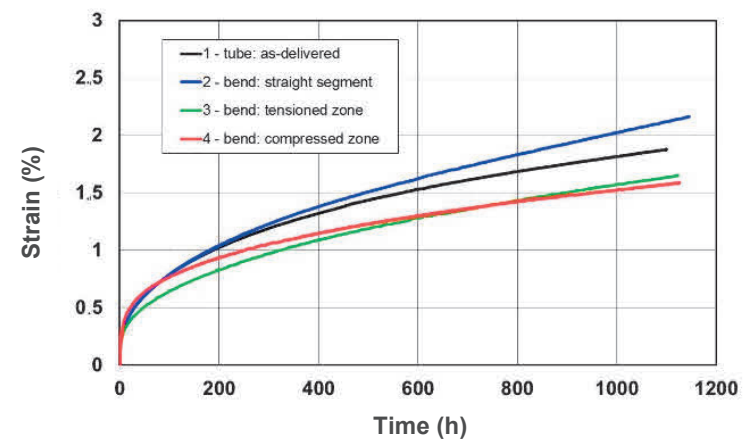

Figure 6 Creep diagrams for the X10CrWMoVNb9-2 steel tube material and bend at a temperature of $600{ }^{\circ} \mathrm{C}$ and stress $162 \mathrm{MPa}$

\section{CONCLUSION}

1) Based on the research it can be concluded that the tube bend made of the X10CrWMoVNb9-2 steel in the analysed process meets the requirements set forth in the PN-EN10216-2 standard. At room temperature, the mechanical characteristics of the bend, i. e. KV, HV10, $R_{m}$ and $R_{p 0,2}$, are comparable to those of the tube material in the as-delivered condition (Table 2).

2) Low-cycle fatigue tests of tube specimens of $\mathrm{X} 10 \mathrm{CrWMoVNb9-2}$ steel in as-delivered condition and from the selected bend zones, showed higher, by about 5-36 \%, low-cycle durability $\mathrm{N}_{\mathrm{f}}$ of the bend material. This proves the decrease in strength properties of the material in the conditions of cyclic loading of an elastic-plastic nature.

3) Analyses of creep tests showed, in zones of tensile and compression of the bend, its deformation $(\varepsilon)$ is lower after the same time, this means behaviour of the material bend is much better in comparison with the as-delivered tube.

4) Based on the presented analyses and discussions of obtained results it should be noted that the parameters of bending and QT heat treatment, adopted in the technological process of fabricating the tube bend from steel X10CrWMoVNb9-2, were properly selected. This contributed eventually to the obtaining of the required quality of the tube bend with regard to the geometrical features and mechanical properties.

\section{ACKNOWLEDGEMENTS}

The research was carried out within the task 1 of the project "The development of innovative technology for production of significantly improved bends of thick-walled steam pipelines" POIG.01.04.00-24-040/12, co-financed from the European Regional Development Fund within the Operational Programme.

\section{REFERENCES}

[1] CIEŚLA, M. and JUNAK, G. Low-cycle fatigue life of steel P92 under gradual loading. Production Editor, IOP Conference Series: Materials Science and Engineering. 2012. vol. 35, 012014, pp. 1-11. 
[2] JUNAK, G. and CIEŚLA, M. Low-cycle fatigue of P91 and P92 steels used in the power engineering industry. Archives of Materials Science and Engineering. 2011. vol. 48, pp. 19-24.

[3] Polish Standard PN-EN 10216-2.

[4] DOBRZAŃSKI, J. Nowej generacji martenzytyczne stale 9-12\% Cr do pracy w warunkach pełzania na elementy krytyczne części ciśnieniowej kotłów energetycznych o nadkrytycznych parametrach pracy. Prace IMŻ 4, 2011.

[5] http://www.jachymek.pl/kompleksowe-rozwiazania-w-zakresie-dostaw-rur-dla-energetyki

[6] TOKARZ A. and ZALECKI, W. Stabilność strukturalna stali P92 w kształtowanych plastycznie elementach rurociągów kotłów energetycznych. [viewed 2016-02-23]. Available from: http://www.iaea.org/inis/collection/NCLCollectionStore/ Public/35/019/35019634.pdf

[7] KOWALEWSKI, Z. Zjawisko pełzania metali - eksperyment i modelowanie. Biblioteka Mechaniki Stosowanej, Warszawa, 2005.

[8] ENNIS, P. J., ZIELIŃSKA-LIPIEC, A., WACHTER, O. and CZYRSKA-FILEMONOWICZ, A. Microstructural stability and creep rupture strength of the martensitic steel P92 for advanced power plant. Acta materialia. 1997. vol. 45, no. 12, pp. 4901-4907.

[9] KUBIŃSKI, W. and KUCZERA, M. Gięcie rur metalowych na gorąco. Obróbka Plastyczna Metali. 2004. no. 4, pp. 23-36.

[10] KUBIŃSKI, W. Wytwarzanie kolan rurowych na gorąco. Hutnik - Wiadomości Hutnicze. 2001. no. 12, pp. 467 471.

[11] PACANOWSKI, J. and KOSOWICZ, Z. Analiza wpływu metody gięcia rur na deformację kolanka rurowego. Rudy i Metale Nieżelazne. 1996. R41, no. 10, pp. 419 - 423.

[12] HU, Z. and LI, J. Q. Computer simulation of pipe-bending processes with small bending radius using local induction heating. Journal of Materials Processing Technology. 1999. vol. 91, pp. 75-79.

[13] TOMCZAK, J., PATER, Z., GONTARZ, A., HADASIK, E., CIEŚLA, M., MUTWIL, K., RZEPKA, W. and KAWAŁA, T. Geometrical phenomena in tube bending with local induction heating. Key Engineering Materials. 2014. Vols. 622-623, pp. 717-724. 